\title{
Comparative Effects of Insulin on Adipose Tissue Segments and Isolated Fat Cells of Rat and Man*
}

\author{
F. Arnold Gries $\ddagger$ and Jürgen Steinke \\ (From the Elliott P. Joslin Research Laboratory, Department of Medicine, Harvard Medical \\ School; the Diabetes Foundation, Inc., and the Peter Bent Brigham Hospital, \\ Boston, Massachusetts)
}

\begin{abstract}
Summary. In vitro metabolism of glucose-1- ${ }^{14} \mathrm{C}$ by adipose tissue into ${ }^{14} \mathrm{CO}_{2}$ and total ${ }^{14} \mathrm{C}$ lipids in rat and man was compared employing both adipose tissue segments and isolated fat cells prepared from the same donor. In the rat, the basal glucose metabolism and response to insulin decreased with increasing body weight for both adipose tissue segments and isolated cells. Regardless of age, the isolated cells exhibited a persistently higher metabolic activity. Of the parameters selected, conversion to $\mathrm{CO}_{2}$ was more pronounced than that to lipid.

In contrast to the rat, in man adipose tissue segments were more active than isolated cells. In four subjects, the effect of 6,50 , and $400 \mu \mathrm{U} / \mathrm{ml}$ of insulin was analyzed on conversion of glucose-1-carbon to $\mathrm{CO}_{2}$, long chain fatty acids, and glycerides by adipose tissue segments only. In 17 subjects, glucose oxidation and lipid synthesis by adipose tissue segments and isolated fat cells were measured and showed a definite response to physiological doses of crystalline pork insulin. There was, however, an age dependency, and consistent effects were obtained with $6 \mu \mathrm{U} / \mathrm{ml}$ in children and $50 \mu \mathrm{U} / \mathrm{ml}$ in adults. The responsiveness of human adipose tissue to exogenous insulin in concentrations comparable to those detected in blood reemphasizes the importance of adipose tissue as a major site for fatty acid synthesis.
\end{abstract}

\section{Introduction}

Most of our knowledge about hormonal effects on the metabolism of fat is derived from experiments with adipose tissue of the rat (1). In light of the variable metabolic behavior of adipose tissue obtained from the different species of laboratory animals $(2,3)$, one might question the rele-

* Submitted for publication 5 October 1966; accepted 8 June 1967.

$\ddagger$ International Postdoctoral Fellow of the United States Public Health Service 2 F05-TW-970-02. Present address: Med. Clinic and Polyclinic, University of Düsseldorf, Germany.

Supported in part by grants from the U. S. Public Health Service, AM-09584-01, T1-AM-05077-10, AM09748-01; and the John A. Hartford Foundation, Inc., New York.

Address requests for reprints to $\mathrm{Dr}$. Jürgen Steinke, Diabetes Foundation, Inc., 170 Pilgrim Road, Boston, Mass., 02215. vance of studies performed in the rat to human adipose tissue metabolism. As a matter of fact, recent data obtained in man seem to indicate that, contrary to the rat, human adipose tissue in vitro is insensitive to physiological doses of insulin (4-7). This hypothesis carries important implications, as it would shift the emphasis from adipose tissue to the liver as the major site of fat synthesis. However, it has been recognized that the poor response of human adipose tissue to insulin may be related to a variety of factors such as dietary preparation of the patient, effects of anesthesia, and methods of collecting the tissue $(4,5)$. Apart from these considerations, rat epididymal fat differs from human subcutaneous fat in its anatomical configuration.

The purpose of this paper was twofold: to make metabolic comparisons between rat and human fat not only between adipose tissue segments but 


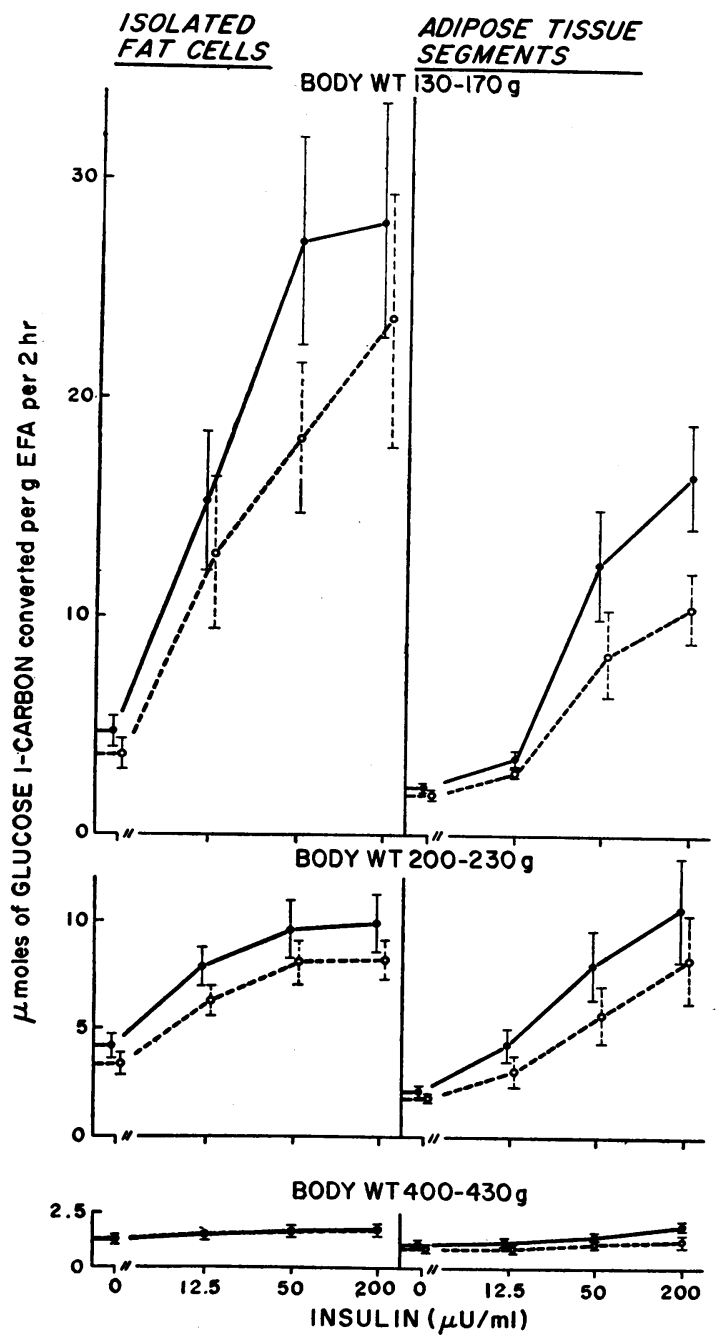

Fig. 1. EFFect OF AGE ON THE INSULIN RESPONSE OF RAT ADIPOSE TISSUE IN vitro. Comparison of the effect of crystalline pork insulin on glucose- $1-{ }^{14} \mathrm{C}$ metabolism by adipose tissue segments and cells from rats of different weight groups; glucose concentration $50 \mathrm{mg} / 100 \mathrm{ml}$, in Krebs-Ringer bicarbonate buffer. Dots and bars represent mean $\pm \mathrm{SE} ; \mathrm{n}=6$ for each group.

, ${ }^{14} \mathrm{CO}_{2}$ production; - - - -, total ${ }^{14} \mathrm{C}$ lipid synthesis. The corresponding ages are : $130-170 \mathrm{~g}, 5-6 \mathrm{wk}$; 200-230 g, 7-8 wk ; 400-430 g, 15-16 wk.

also between isolated fat cells; and to establish the lowest metabolically effective insulin dose. A preliminary report of this work has appeared in abstract form (8).

\section{Methods}

Rats were obtained from an inbred albino strain (Charles River Farms Breeding Laboratory, North Wilmington, Mass.). They had free access to tap water and
Purina chow until they were sacrificed by a guillotine between 8 and 10 a.m. Epididymal fat pads were immediately removed and tissue segments obtained from the distal part, which weighed between 60 and $100 \mathrm{mg}$; isolated fat cells were prepared from the proximal portions of similar weight.

Samples of human subcutaneous adipose tissue were obtained from either the abdominal wall or back of patients. The subjects ranged in age from 5 to $80 \mathrm{yr}$ and were selected for lack of metabolic disease. In all instances, surgery was elective and performed after an overnight fast. Preoperative medication was morphine or morphine derivatives with atropine and Nembutal. Special care was taken to avoid any infusion of glucose in the immediate preoperative period. If fluid was administered to maintain an "open vein," it consisted of isotonic saline. General anesthesia was performed with halothane and nitrous oxide. Subcutaneous fat was excised as soon as feasible and placed into warm KrebsRinger bicarbonate buffer, immediately taken to the laboratory, and prepared for incubation. Coarse elements of connective tissue were carefully dissected free. The fat was cut with scissors into strips measuring $2 \times$ $10 \mathrm{~mm}$ or less, which were used as such or from which isolated fat cells were prepared. The time interval between excision from the patient and initiation of incubation was less than $7 \mathrm{~min}$.

Fat cells from rat and human adipose tissue were isolated by collagenase (Worthington Biochemical Corporation, Freehold, N. J., lot No. CLS-65102, CLS-6EA), according to Rodbell (9). The serum albumin employed in the incubation medium was Armour's Fraction V (lot No. B-23407). It was dialyzed against distilled water, filtered through Millipore Filter HA $0.45 \mu$ (Millipore Filter Corp., Bedford, Mass.), and lyophilized. Incubations of both rat and human isolated fat cells and tissue segments were carried out in Krebs-Ringer bicarbonate buffer containing $4 \mathrm{~g} / 100 \mathrm{ml}$ of albumin, prepared as described above, and variable glucose concentrations as indicated under Results. The concentration of glucose $-1{ }^{14} \mathrm{C}$ (New England Nuclear Corp., Boston, Mass.) was 0.1 $\mu \mathrm{c} / 1.1 \mathrm{ml}$ of buffer; the final glucose concentration was adjusted with unlabeled glucose. After 2 or $3 \mathrm{hr}$ of incubation, the reaction was interrupted by addition of 0.2 $\mathrm{ml}$ of $10 \mathrm{~N}$ sulfuric acid. ${ }^{14} \mathrm{CO}_{2}$ was trapped and radioactivity counted as previously described (10). Total lipids were extracted according to Folch et al. (11). Esterified fatty acids (EFA) in the extracts were determined according to Rosenthal et al. (12). The results were expressed as milligrams of EFA, assuming an average molecular weight of the fatty acids of 277 . The incorporation of ${ }^{14} \mathrm{C}$ into fatty acids or glycerideglycerol was analyzed according to Cahill et al. (13). The nitrogen $(\mathrm{N})$ content of adipose tissue segments was determined with Nessler's reagent $(14,15)$ on digested tissue which had not been incubated in albumin-containing buffer, after first extracting the lipid to determine EFA content. In experiments with isolated fat cells, the $\mathrm{N}$ content was calculated from the EFA, assuming that the $\mathrm{N}$ content per $\mathrm{g}$ of EFA was similar in tissue seg- 
ments and cells from the same sample. Due to the limited amount of adipose tissue, $\mathrm{N}$ content was determined on only a few of the same specimens in young rats and in man. In all other cases, analyses were performed on adipose tissue of subjects or animals matched for age and weight with those used for the metabolic studies.

Crystalline pork insulin (lot No. 723603) was obtained from Eli Lilly \& Co., Indianapolis, Ind., courtesy of Dr. W. Kirtley.

\section{Results}

Rat adipose tissue. Comparative studies on isolated fat cells and adipose tissue segments obtained from the same animal were performed on rats of different weight, i.e., age, with tissue segments or isolated fat cells equivalent to $40-60 \mathrm{mg}$ of EFA per $\mathrm{ml}$ of medium. Since the number of epididymal fat segments which could be obtained from smaller animals was limited, the comparison was restricted to three different insulin concentrations, $12.5,50$, and $200 \mu \mathrm{U} / \mathrm{ml}$. The results are summarized in Fig. 1. In general, the basal glucose metabolism of adipose tissue segments and cells, as well as the insulin response, decreased with increasing weight of the rats. When segments and cells of each individual rat were compared,
TABLE I

Nitrogen content of adipose tissue from rats and men of different ages

\begin{tabular}{lrrr}
\hline \hline & & & \multicolumn{1}{c}{ mg N/g EFA } \\
& $\mathrm{n}$ & \multicolumn{1}{c}{ Age } & $\begin{array}{c}\text { mean } \pm \text { SD } \\
\text { Rats* }\end{array}$ \\
& 6 & $5-6 \mathrm{wk}$ & $4.22 \pm 0.28$ \\
& 6 & $7-8 \mathrm{wk}$ & $4.21 \pm 0.51$ \\
& 6 & $15-16 \mathrm{wk}$ & $2.45 \pm 0.23$ \\
Human & 4 & $5-15 \mathrm{yr}$ & $4.04 \pm 2.17$ \\
subjects + & 13 & $23-69 \mathrm{yr}$ & $3.55 \pm 1.08$
\end{tabular}

* Epididymal fat.

‡ Subcutaneous fat.

the cells exhibited a higher base line activity and a steeper response curve to insulin. The latter, however, exhibited an early plateau which occurred, for $\mathrm{CO}_{2}$ production, at an insulin level of 50 $\mu \mathrm{U} / \mathrm{ml}$. In both tissue segments and isolated cells, there was a more pronounced conversion of 1 -carbon into ${ }^{14} \mathrm{CO}_{2}$ than into ${ }^{14} \mathrm{C}$ lipids. The $\mathrm{N}$ content of adipose tissue obtained from rats and men of different age groups is summarized in Table I. With advancing age in rats, there was a decrease in $\mathrm{N}$ content; however, in men, this was not significant for the groups studied.
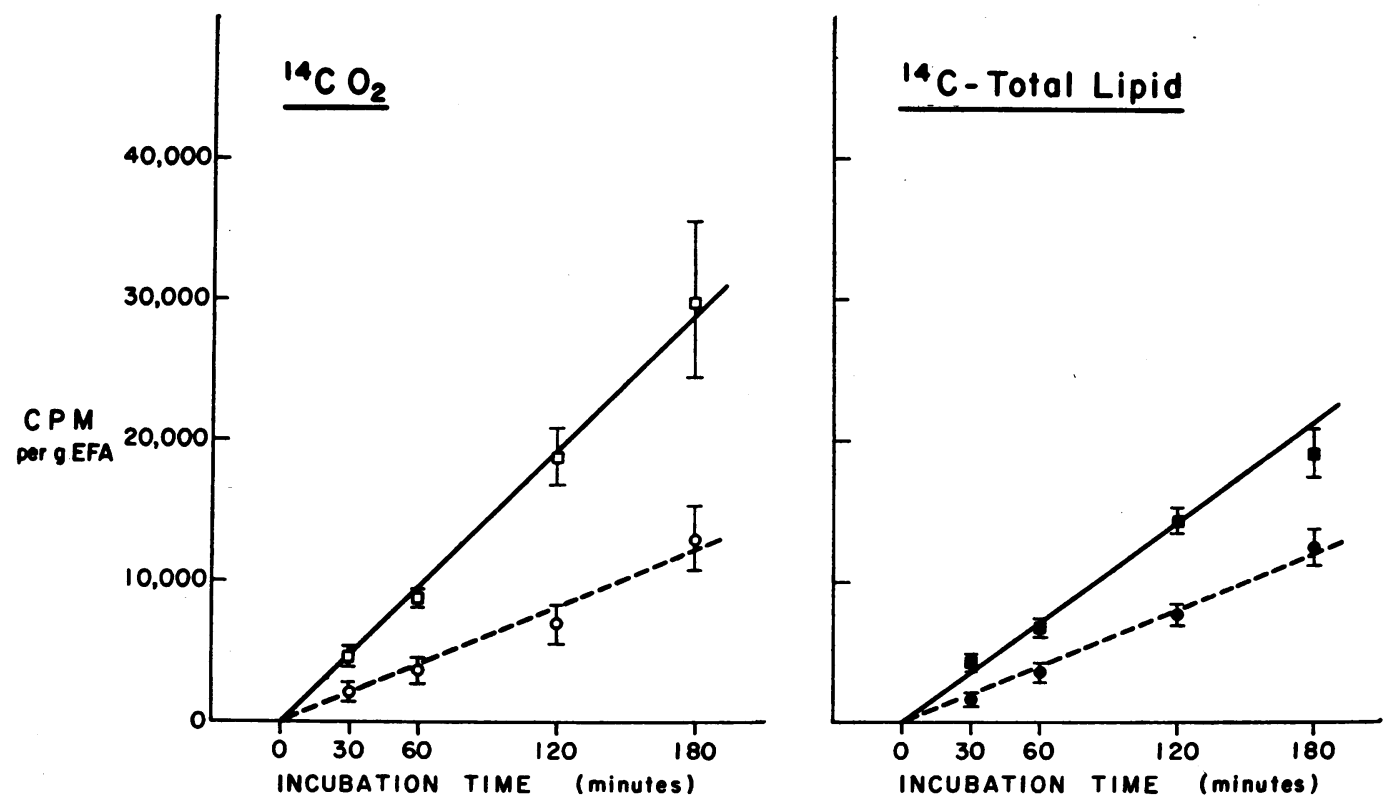

Fig. 2. Human adipose tisSUe SEgments: EFFECT OF INCUBation time on inCorporation of GLUCOSE- $1-{ }^{14} \mathrm{C}$ into ${ }^{14} \mathrm{CO}_{2}$ aNd ${ }^{14} \mathrm{C}$ TOTAL LIPIDS BY HUMAN SUbCUTANEOUS FAT. Dots and bars represent mean \pm SE $(n=5)$.

_. - - Krebs-Ringer bicarbonate buffer, $50 \mathrm{mg}$ of glucose per $100 \mathrm{ml}$; Krebs-Ringer bicarbonate buffer, $50 \mathrm{mg}$ of glucose per $100 \mathrm{ml}$ plus $1000 \mu \mathrm{U} / \mathrm{ml}$ of crystalline pork insulin. 

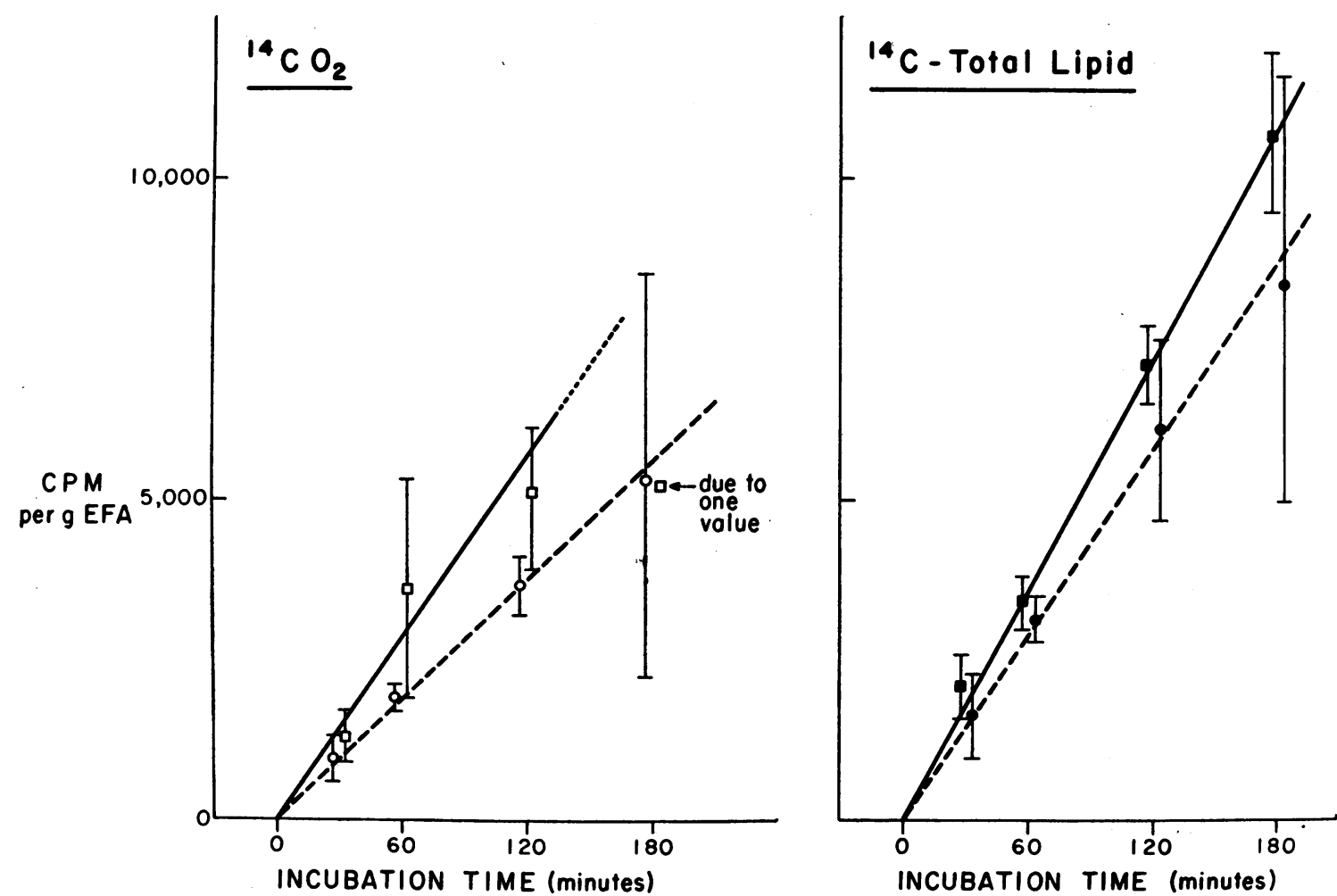

Fig. 3. Human adipose tissue cells: effect of incubation time on incorporation of glucose-1- ${ }^{14} \mathrm{C}$ into ${ }^{14} \mathrm{CO}_{2}$ AND ${ }^{14} \mathrm{C}$ TOTAL LIPIDS. Dots and bars represent mean $\pm \mathrm{SE}(\mathrm{n}=5)$.

- - - , Krebs-Ringer bicarbonate buffer, $50 \mathrm{mg}$ of glucose per $100 \mathrm{ml}$; buffer, $50 \mathrm{mg}$ of glucose per $100 \mathrm{ml}$, plus $1000 \mu \mathrm{U} / \mathrm{ml}$ of crystalline pork insulin.

Krebs-Ringer bicarbonate

Studies on human adipose tissue. The rate of $\mathrm{CO}_{2}$ production and incorporation of glucose into lipid was studied in human adipose tissue during a $3 \mathrm{hr}$ incubation period with $40-80 \mathrm{mg}$ of EFA per $\mathrm{ml}$ of medium of isolated fat cells or tissue segments. The relative linearity of the metabolic rate of adipose tissue segments is shown in Fig. 2 and that of isolated cells in Fig. 3. There was a greater variability with cells than with tissue segments. All other incubations of human adipose tissue were performed for $2 \mathrm{hr}$.

The effect of crystalline insulin on segments of adipose tissue and on isolated cells using 40-60 $\mathrm{mg}$ of EFA per $\mathrm{ml}$ of medium was studied on specimens from 17 subjects. They ranged in age from 5 to $80 \mathrm{yr}$. Fig. 4 demonstrates an insulin dose response curve for these subjects divided into three age groups. On fat of patients below the age of sixteen, a significant $(P<0.01)$ insulin effect could be detected at an insulin level of $6 \mu \mathrm{U} / \mathrm{ml}$; in adults a significant insulin effect was not seen at $6 \mu \mathrm{U} / \mathrm{ml}$, but was seen at the next higher level tested, namely $50 \mu \mathrm{U} / \mathrm{ml}(P<0.05)$. The decreasing insulin sensitivity of adipose tissue segments with advancing age is documented in Fig. 5, which shows the absolute data for each individual for $\mathrm{CO}_{2}$ production and lipid synthesis in the presence and absence of $400 \mu \mathrm{U} / \mathrm{ml}$ of insulin. Fig. 6 shows the mean data for each of the three different age groups obtained with adipose tissue segments as well as with isolated cells, both with and without insulin stimulation. It is noteworthy that, regardless of the age of the subject, in the presence of insulin, tissue segments were metabolically more active than cells. This was most pronounced with fat obtained from childrèn. The increase of $\mathrm{CO}_{2}$ production and total lipid synthesis above base line induced by $400 \mu \mathrm{U} / \mathrm{ml}$ of insulin was $280 \%$ in children, $113 \%$ in adults $20-49 \mathrm{yr}$ old, but only $84 \%$ in subjects over $50 \mathrm{yr}$ of age.

We also analyzed the effect of 6,50 , and 400 
$\mu \mathrm{U} / \mathrm{ml}$ of insulin on the incorporation by adipose tissue segments of glucose- $1-{ }^{14} \mathrm{C}$ into ${ }^{14} \mathrm{CO}_{2}$, total lipid, long chain fatty acids, and glyceride-glycerol in four subjects, ranging in age from 7 to $59 \mathrm{yr}$ (Table II). In agreement with the literature (4-7), under base line conditions, $85 \%$ of the radioactivity was incorporated into total lipid as glyceride-glycerol ; labeling of fatty acids was minimal. Whereas ${ }^{14} \mathrm{C}$ glyceride-glycerol formation was insensitive to added insulin, $6 \mu \mathrm{U} / \mathrm{ml}$ induced a significant increase of incorporation of glucose1-carbon into fatty acids and $\mathrm{CO}_{2}$. This was most pronounced in the youngest subject.

\section{Discussion}

Recently Rodbell (9) has introduced the isolated fat cell preparation. Although its response

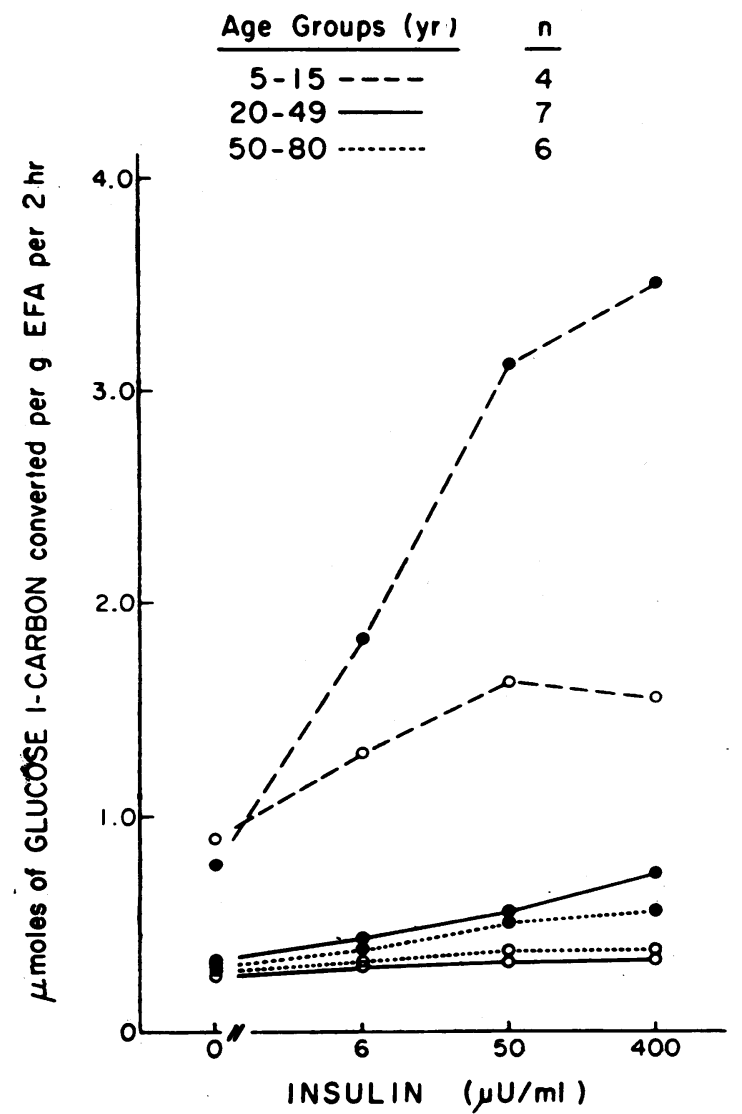

Fig. 4. EFFeCt OF various concentrations OF CRYSTALLINE PORK INSULIN ON ${ }^{16} \mathrm{CO}_{2}$ PRODUCTION FROM GLUCOSE-1- ${ }^{14} \mathrm{C}$ BY SUBCUTANEOUS ADIPOSE TISSUE SEGMENTS (๑) AND ISOLATED CELLS (O) FROM HUMAN SUBJECTS OF DIFFERENT AGE GROUPS.
TABLE II

Effect of various concentrations of crystalline prek insulin on incorporation of glucose-1-14 C into $\mathrm{CO}_{2}$, total lipid, fatty acids, and glyceride-glycerol by human subcutanesus adipose tissue segments

\begin{tabular}{|c|c|c|c|c|c|c|c|}
\hline \multirow{2}{*}{$\begin{array}{c}\text { Conversion of } \\
\text { glucose-1- } \\
\text { carbon per } \mathrm{g} \\
\text { EFA per } 2 \mathrm{hr} \\
\text { into: }\end{array}$} & \multirow[b]{2}{*}{ Subject } & \multirow[b]{2}{*}{ Age } & \multirow[b]{2}{*}{ Sex } & \multicolumn{4}{|c|}{ Insulin concentration } \\
\hline & & & & 0* & $6^{*}$ & $50 *$ & 400* \\
\hline & & & & \multicolumn{4}{|c|}{$\mu U / m l$} \\
\hline \multirow[t]{5}{*}{${ }^{14} \mathrm{CO}_{2}$} & 1 & 7 & $\mathbf{M}$ & 0.670 & 395 & 497 & 585 \\
\hline & 2 & 11 & $\mathbf{F}$ & 0.875 & 115 & 330 & 350 \\
\hline & 3 & 28 & $\mathbf{M}$ & 0.239 & 162 & 237 & 295 \\
\hline & 4 & 59 & $\mathbf{F}$ & 0.310 & 188 & 315 & 350 \\
\hline & Mean & & & 0.524 & 215 & 345 & 395 \\
\hline \multirow[t]{5}{*}{${ }^{14} \mathrm{C}$-total lipid } & 1 & & & 1.700 & 142 & 188 & 208 \\
\hline & 2 & & & 0.960 & 120 & 262 & 282 \\
\hline & 3 & & & 0.360 & 135 & 189 & 220 \\
\hline & 4 & & & 0.343 & 152 & 187 & 228 \\
\hline & Mean & & & 0.841 & 137 & 207 & 235 \\
\hline \multirow[t]{5}{*}{${ }^{14} \mathrm{C}$-fatty acids } & 1 & & & 0.130 & 910 & 1535 & 1690 \\
\hline & 2 & & & 0.232 & 142 & 695 & 725 \\
\hline & 3 & & & 0.028 & 274 & 478 & 885 \\
\hline & 4 & & & 0.094 & 147 & 620 & 1470 \\
\hline & Mean & & & 0.121 & 368 & 582 & 1193 \\
\hline \multirow{5}{*}{$\begin{array}{l}{ }^{14} \mathrm{C} \text {-glyceride- } \\
\text { glycerol }\end{array}$} & 1 & & & 1.625 & 105 & 99 & 97 \\
\hline & 2 & & & 0.605 & 118 & 131 & 124 \\
\hline & 3 & & & 0.347 & 122 & 147 & 135 \\
\hline & 4 & & & 0.300 & 139 & 159 & 175 \\
\hline & Mean & & & 0.719 & 121 & 134 & 133 \\
\hline
\end{tabular}

* The values listed under 0 insulin level represent the number of $\mu$ moles of glucose-1-carbon converted into the compound indicated. The values listed under the 3 insulin levels tested represent the per cent of base line ( 0 insulin) value.

to various hormones has been shown to be similar to that of segments of adipose tissue $(9,16,17)$, a direct comparison between cells and segments of adipose tissue from individual animals has not been previously made.

In the rat, when measured by the incorporation of ${ }^{14} \mathrm{C}$ from glucose- $1-{ }^{14} \mathrm{C}$ into $\mathrm{CO}_{2}$ and total lipid, basal glucose metabolism of isolated cells was higher than that of respective adipose tissue segments. Alterations of the cell membrane due to the isolation procedure are unlikely to be responsible for the higher metabolic rate of isolated fat cells, as addition of collagenase to them did not stimulate but rather appeared to inhibit the basal glucose metabolism (data not shown). Furthermore they have been shown to be unimpaired in their osmotic behavior (18) and in their ability to exclude sucrose and insulin (19). Finally, isolated cells from rats remain at least as sensitive to insulin as adipose tissue segments (Fig. 1), again suggesting an intact cell membrane function. 


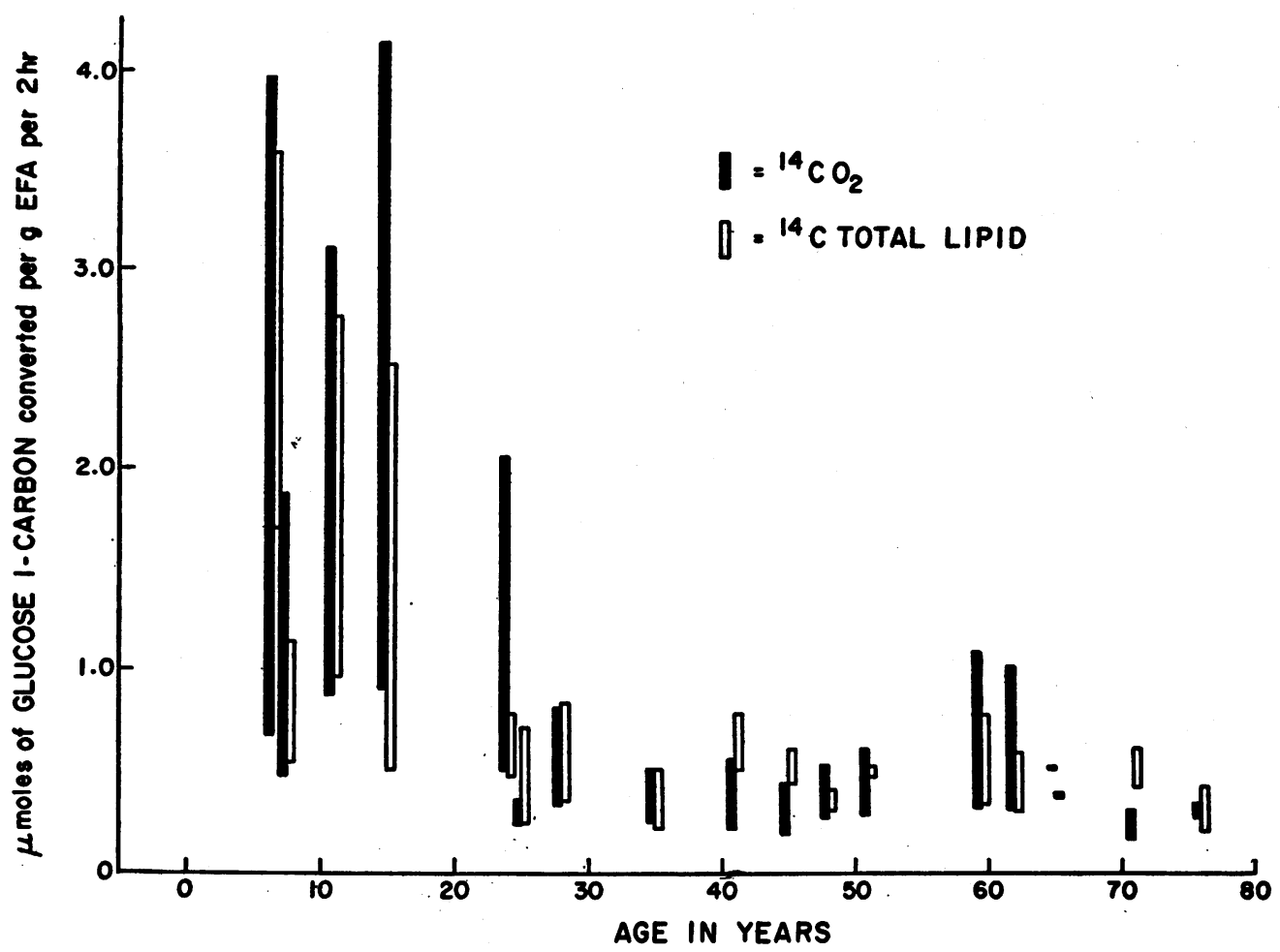

Fig. 5. Human sUbcutaneous adipose tissue SEgments: INCORPORATION OF GLUCOSE-1 $1{ }^{14} \mathrm{C}$ into $\mathrm{CO}_{2}$ AND TOTAL LIPID. Individual data of 17 subjects according to age. The base of the column indicates base line metabolism; the top represents values after stimulation with $400 \mu \mathrm{U} / \mathrm{ml}$ of crystalline pork insulin.

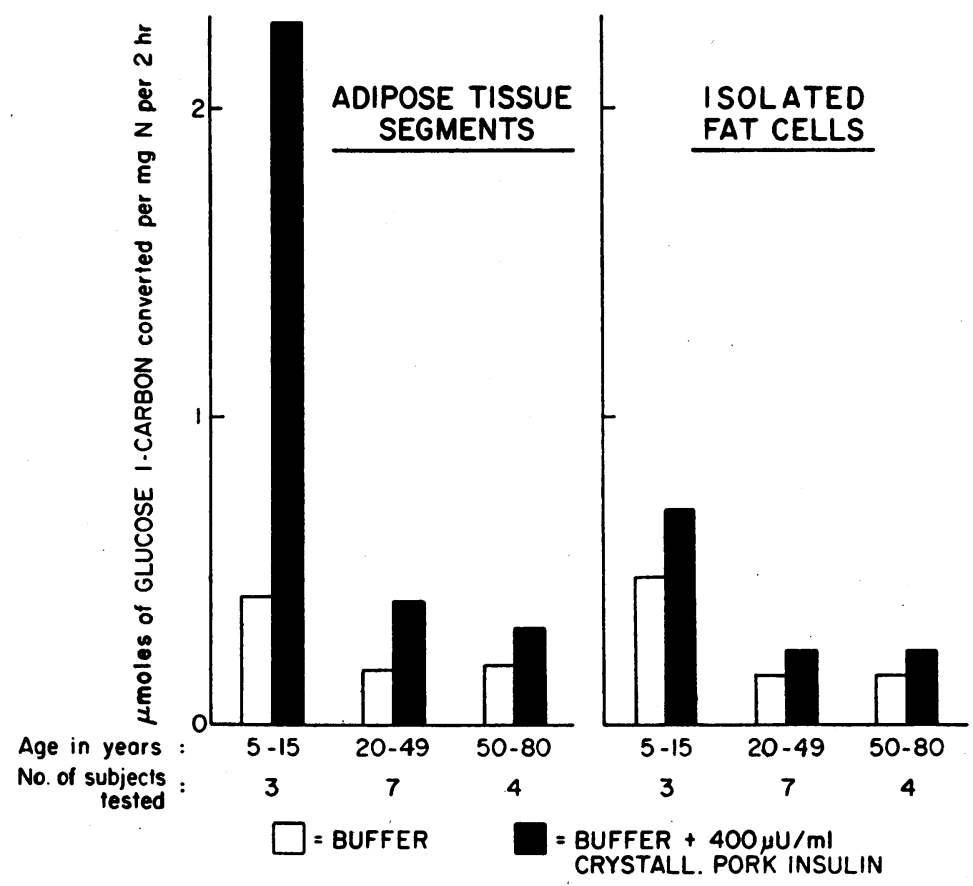

Fig. 6. EFFect of $400 \mu \mathrm{U} / \mathrm{ml}$ of insulin on GLUCOSE-1- ${ }^{14} \mathrm{C}$ MEtaboLISM AS MEASURED BY ${ }^{14} \mathrm{CO}_{2}$ PRODUCTION AND ${ }^{14} \mathrm{C}$ LIPID SYNTHESIS BY HUMAN SUBCUTANEOUS ADIPOSE TISSUE SEgMENTS AND CELlS OBTAINED FROM PATIENTS OF VARIOUS AGES. 
On the other hand, it has been established that the basal glucose metabolism of adipose tissue depends on the glucose concentration in the medium (20). As glucose is continuously being extracted by the fat cell, one might expect a glucose gradient between medium and cell membrane. The presence of connective tissue in adipose tissue segments would increase the time required for equilibration between medium and fat cell, as glucose will have to traverse additional space. That this indeed requires time has been shown for sorbitol in rat and human adipose tissue $(6,21)$. If this is applicable to diffusion of glucose, it would explain the lesser metabolic activity of rat adipose tissue segments, when compared to that of isolated fat cells.

In addition to exhibiting a greater basal glucose metabolism, isolated rat fat cells responded more markedly to insulin. A potentiation of the hormone effect of collagenase can be excluded, since collagenase as a proteolytic enzyme inactivates the hormone (data not shown). The apparent increment of insulin response of isolated fat cells could be explained by an insulin gradient in the tissue similar to that outlined for glucose.

Rat epididymal adipose tissue, when compared to subcutaneous human fat, produced more $\mathrm{CO}_{2}$ but less total lipid; the ratio of total lipid $/ \mathrm{CO}_{2}$ was less for rat tissue. This may be a peculiarity of rat epididymal adipose tissue (22).

In man, the difference in basal metabolism between isolated fat cells and segments of adipose tissue was smaller or absent. This does not necessarily indicate less activity since, in contrast to the rat, human isolated fat cells were frequently accompanied by macroscopic fat droplets. The presence of these droplets indicated the occurrence of cell rupture during the preparation of the isolated cells. The observed variable metabolic rate during a $3 \mathrm{hr}$ incubation (Fig. 3) may be due to a variable degree of such cell rupture. Thus, because of the unknown amounts of free (extracellular) lipid, the amount of fat cells in the incubate might be overestimated, and, consequently, their metabolic rate underestimated. In the light of these observations, studies of human fat would appear more reliable with adipose tissue segments than with isolated fat cells.

Base line activity of tissue segments was found to be age dependent (Figs. 5 and 6 ). This age dependency is similar to that of the rat reported by others $(22,23)$ and confirmed in this study, in which it was observed with tissue segments as well as with isolated cells (Figs. 1, 4, and 6). The decrease in metabolism can, in part, be explained by a diminution of the $\mathrm{N}$ content per $\mathrm{g}$ of EFA. However, in both man and rat, the $\mathrm{N}$ content of adipose tissue decreased less than did basal glucose metabolism.

The response of human fat in vitro to crystalline insulin in small doses was observed with both tissue segments and cells, although it was most pronounced with the former and when obtained from young people. Even though older people were relatively more "insulin-resistant," they did respond to $50 \mu \mathrm{U} / \mathrm{ml}$ of insulin. The blunted insulin response. with advancing age was also observed with tissue from rats; and, for comparison, fat from human adults behaved similar to that from a $400 \mathrm{~g}$ rat, that from children similar to adipose tissue from a $200 \mathrm{~g}$, growing rat. Caution, however, must be exercised when such comparisons are made between species, as metabolic activities of adipose tissue will vary in different anatomical sites within a single species, as has been shown for the rat (22) as well as for man (24).

In man, adipose tissue segments were more active than cells. As tissue factors have been eliminated in the cell preparation, it is conceivable that isolated cells may inactivate insulin. Preliminary data obtained in this laboratory support such a hypothesis. Crystalline insulin, measured in aliquots during a $3 \mathrm{hr}$ incubation either with buffer alone, with adipose tissue segments, or with isolated cells, disappeared to a larger degree in the presence of cells than with tissue segments.

Previous reports describe an insulin effect on glucose metabolism by human adipose tissue only with pharmacological doses of either $100 \mathrm{mU} / \mathrm{ml}$ $(25,26,4-6)$ or $10 \mathrm{mU} / \mathrm{ml}$ of insulin (7). Since completion of our work, Owen et al. (27) obtained a significant effect on adipose tissue segments of normal subjects with an insulin concentration of $500 \mu \mathrm{U} / \mathrm{ml}$. Factors which retrospectively may be of importance to observe the insulin sensitivity of adipose tissue are: (a) avoidance of any intravenous infusion containing glucose preceding the operation in order to prevent any elevation of the patient's endogenous insulin and, 
thus, already maximally stimulating his adipose tissue in situ; (b) surgical excision, rather than needle biopsy, of the adipose tissue to minimize any traumatization; and $(c)$ speedy delivery to the laboratory within minutes after excision, followed by immediate incubation.

Although we found adipose tissue of children to be more sensitive to insulin than that of adults, the insulin concentrations which significantly enhanced glucose metabolism in both were within the range measured in man during glucose tolerance tests by insulin immunoassay (28). Our findings, therefore, may have physiological implications, inasmuch as they would reemphasize that in man, as in the rat, adipose tissue is a major site of fatty acid synthesis. Recently (29), due to the reportedly sluggish in vitro response of human adipose tissue to insulin, it had been implied that in man the liver is the major organ involved with fatty synthesis.

\section{Acknowledgments}

We are greatly indebted to the members of the surgical staff of the New England Deaconess Hospital and Children's Medical Center, Boston, Mass., for providing adipose tissue samples. The expert technical assistance of Mrs. M. Grinbush is gratefully acknowledged.

\section{References}

1. A. E., Renold, and G. F. Cahill, Jr., editors. 1965. Adipose tissue. In Handbook of Physiology. American Physiological Society. Section 5. 1.

2. Steinke, J., E. Miki, and G. F. Cahill, Jr. 1965. Assay of crystalline insulin and of serum insulinlike activity of different species on adipose tissue of the rat, mouse and guinea pig. New Engl. J. Med. $273: 1465$.

3. DiGirolamo, M., and D. Rudman. 1966. Species differences in glucose metabolism and insulin responsiveness of adipose tissue. Am. J. Physiol. 210: 721 .

4. Hirsch, J., and R. B. Goldrick. 1964. Serial studies on the metabolism of human adipose tissue. I. Lipogenesis and free fatty acid uptake and release in small aspirated samples of subcutaneous fat. J. Clin. Invest. 43: 1776.

5. Kahlenberg, A., and N. Kalant. 1964. The effect of insulin on human adipose tissue. Can. J. Biochem. 42: 1623.

6. Fessler, A., and J. C. Beck. 1965. The effect of insulin on the metabolism of human adipose tissue in vitro. Biochim. Biophys. Acta. 106: 199.

7. Björntorp, P. 1966. Studies on adipose tissue from obese patients with or without diabetes mellitus.
II. Basal and insulin stimulated glucose metabolism. Acta Med. Scand. 179: 229.

8. Gries, F. A., and J. Steinke. 1966. Comparative effect of insulin on $\mathrm{C}^{14} \mathrm{O}_{2}$ production and lipid synthesis from 1-C-14 glucose in adipose tissue slices and isolated fat cells from man and rat. Fed. Proc. 25 : 441. (Abstr.)

9. Rodbell, M. 1964. Metabolism of isolated fat cells. I. Effects of hormones on glucose metabolism and lipolysis. J. Biol. Chem. 239: 375.

10. Steinke, J., J. S. Soeldner, R. A. Camerini-Davalos, and A. E. Renold. 1963. Studies on serum insulin-like activity (ILA) in prediabetes and early overt diabetes. Diabctes. 12 : 502 .

11. Folch, J., M. Lees, and G. H. Sloane Stanley. 1957. A simple method for the isolation and purification of total lipids from animal tissues. J. Biol. Chem. 226: 497.

12. Rosenthal, H. L., M. L. Pfluke, and J. Callerami. 1959. The colorimetric estimation of serum fatty esters. Clin. Chim. Acta. $4: 329$.

13. Cahill, G. F., Jr., B. Leboeuf, and A. E. Renold. 1959. Studies on rat adipose tissue in vitro. III. Synthesis of glycogen and glyceride-glycerol. $J$. Biol. Chem. 234 : 2540.

14. Folin, O., and W. Denis. 1916. Nitrogen determination by direct Nesslerization. I. Total nitrogen in urine. J. Biol. Chem. 26: 473.

15. Wong, S. Y. 1923. The use of persulfate in the estimation of nitrogen by Folin's direct Nesslerization method. J. Biol. Chem. $55: 431$.

16. Fain, J. N., V. P. Kovacev, and R. O. Scow. 1965. Effect of growth hormone and dexamethasone on lipolysis and metabolism in isolated fat cells of the rat. J. Biol. Chem. 240: 3522 .

17. Fain, J. N., D. J. Galton, and V. P. Kovacev. 1966. Effect of drugs on the lipolytic action of hormones in isolated fat cells. Mol. Pharmacology. 2: 237.

18. Lech, J. J., and D. N. Calvert. 1966. Protein content and osmotic behavior of isolated fat cells. J. Lipid Res. 7 : 561.

19. Renold, A. E., A. Gonet, O. B. Crofford, and D. Vecchio. 1966. Metabolic regulation in heterogeneous systems: Some new questions about diabetes mellitus. Fed. Proc. $25: 827$.

20. Jeanrenaud, B., and A. E. Renold. 1959. Studies on rat adipose tissue in vitro. IV. Metabolic pattern produced in rat adipose tissue by varying insulin and glucose concentrations independently from each other. J. Biol. Chem. 234: 3082.

21. Crofford, O. B., and A. E. Renold. 1965. Glucose uptake by incubated rat epididymal adipose tissue. Rate limiting steps and site of insulin action. $J$. Biol. Chem. 240: 14.

22. Benjamin, W., A. Gelhorn, M. Wagner, and $H$. Kundel. 1961. Effect of aging on lipid composition and metabolism in the adipose tissue of the rat. Am. J. Phys. 201 : 540. 
23. Ball, E. G., and O. Cooper. 1960. Studies on the metabolism of adipose tissue. III. The response to insulin by different types of adipose tissue and in the presence of various metabolites. J. Biol. Chem. 235 : 584.

24. Hamosh, M., P. Hamosh, J. A. Bar-Maor, and P. Cohen. 1963. Fatty acid metabolism by human adipose tissue. J. Clin. Invest. 42: 1648.

25. Field, J. B., P. Johnson, and B. Herring. 1961. Insulin-resistant diabetes associated with increased endogenous plasma insulin followed by complete remission. J. Clin. Invest. 40: 1672.

26. Pozza, G., A. Ghidoni, and C. Basilico. 1963. Glucose uptake and gas exchange in human adipose tissue incubated in vitro. (Letter to the Editor) Lancet. I: 836 .

27. Owen, J. A., Jr., R. W. Lindsay, J. H. Gaskin, and G. Hollifield. 1967. Response of human adipose tissue to endogenous serum insulin-like activity in vitro. Metabolism. 16: 47.

28. Yalow, R. A., and S. A. Berson. 1960. Plasma insulin concentrations in non-diabetic and early diabetic subjects. Determinations by a new sensitive immuno-assay technic. Diabetes. 9: 254.

29. Farquhar, J. W., A. Frank, R. C. Gross, and G. M. Reaven. 1966. Glucose, insulin, and triglyceride responses to high and low carbohydrate diets in man. J. Clin. Invest. 45: 1948. 